This item was submitted to Loughborough's Research Repository by the author.

Items in Figshare are protected by copyright, with all rights reserved, unless otherwise indicated.

\title{
Impact sourcing ventures and local communities: a frame alignment perspective
}

\section{PLEASE CITE THE PUBLISHED VERSION}

http://dx.doi.org/10.1111/isj.12057

\section{PUBLISHER}

(c) Wiley Publishing Ltd

\section{VERSION}

AM (Accepted Manuscript)

\section{PUBLISHER STATEMENT}

This work is made available according to the conditions of the Creative Commons Attribution-NonCommercialNoDerivatives 4.0 International (CC BY-NC-ND 4.0) licence. Full details of this licence are available at: https://creativecommons.org/licenses/by-nc-nd/4.0/

\section{LICENCE}

CC BY-NC-ND 4.0

\section{REPOSITORY RECORD}

Sandeep, M.S., and Ravishankar Mayasandra-Nagaraja. 2019. "Impact Sourcing Ventures and Local Communities: A Frame Alignment Perspective”. figshare. https://hdl.handle.net/2134/16919. 


\title{
Impact sourcing ventures and local communities: A frame alignment perspective
}

\begin{abstract}
Using qualitative methods this paper explores how impact sourcing (ImS) ventures frame their activities to marginalized communities. In doing so, the paper attempts to unearth the social-psychological processes undergirding ImS strategies. The findings highlight the difficulties faced by ImS ventures in operationalizing their strategic intent. More specifically, the paper provides insights into how different and diverse framings are used by ImS ventures to influence the local community. From a strategic perspective the paper suggests that framings related to progress, family, material-benefit and egalitarianism can help overcome the inevitable tensions and misunderstandings with the community. Drawing on the findings, we develop a process model which describes how competing framings of an ImS venture and the community could eventually align. Theoretically, the paper illuminates the day to day micro-processes of reality negotiation between socially driven IT-BPO businesses and the local communities they seek to impact.
\end{abstract}

\section{Keywords:}

Impact sourcing, frame alignment, India, ethnography, IT-BPO 


\section{INTRODUCTION}

Newly emerging information technology (IT) - enabled sourcing models are not just about 'business' (Heeks \& Arun, 2010; Heeks, 2013; Madon \& Sharanappa, 2013). Some of these models are also guided by a strong underlying social mission to 'do good' and create 'social value' (Carmel et al. 2013; Lacity et al., 2014; Sandeep \& Ravishankar, 2013). Collectively they are now being referred to as impact sourcing (ImS). Carmel et al., (2013, pp. 5) define ImS as 'the practice of training and hiring marginalized individuals...to provide information technology, business process, or other digitally-enabled services'. The ImS business model consciously provides employment opportunities to communities and groups whose life chances are deemed poor (see Lacity et al., 2014). In this paper, 'ImS ventures' refer to such information technology (IT) - business process outsourcing (BPO) vendor firms, which aim to create a significant 'impact' (hence the term 'impact sourcing') on the lives of hitherto disadvantaged and deprived communities by giving them gainful employment and thereby improving their material conditions.

The socio-economic potential of ImS ventures is mostly explained using rational market-based considerations and the argument is made that ImS is a neat business opportunity given the many possibilities for dynamic entrepreneurs to serve the 'bottom of the pyramid'1 (see Heeks, 2013). This high-level view makes optimistic forecasts about the a) economic benefits of ImS for clients (Accenture, 2012) and the b) social good that can be delivered in the process (Monitor, 2011; Accenture, 2012). Recent figures suggest that ImS ventures will create 561,000 jobs at the bottom of the pyramid and generate annual revenues of US $\$ 20$ billion by 2015 (Carmel et al., 2013). However, despite its obvious promise the ImS model faces some serious stumbling blocks. Extant projections appear to implicitly assume that community participants are eagerly waiting to support the ImS model (see KPMG, 2012). And if they are not, it is expected that they will quickly recognize the benefits of ImS and hence, embrace such ventures wholeheartedly (see Accenture 2013; Sandeep \& Ravishankar, 2013). The broader business and management literature, however, warns that the optimism surrounding such socially-oriented business models could be misplaced and that the idea of the community as being welcoming and evergrateful could be too simplistic (see Marquis \& Battilana, 2009; Seelos et al., 2010).

\footnotetext{
${ }^{1}$ Bottom of the pyramid broadly refers to the poorest socio-economic groups in the world (see Prahalad \& Hart, 2002)
} 
For instance, research has shown how social enterprises have been forced to drastically rethink and redesign their blended 'social-commercial' business models because of a lack of support from the local community, which views such models from very different cultural, social and ideological bases (see Thompson \& Macmillan, 2010; Bandyopadhyay \& Unnikrishnan, 2013). Against this background, in this paper we suggest that the degree to which ImS ventures can meet their social and business goals may be closely linked to their ability to frame activities and operations in ways that overcome the competing framings of the community. Broadly, we address the key question "how do companies frame their ImS ventures to the local community?"

We draw on the frame alignment literature, which argues that different groups frame 'reality' differently in line with their respective world-views and normative orientations (Goffman, 1974; Snow et al., 1986). For instance, in IT offshoring relationships while onshore groups tend to view offshore groups in their company through a 'low-status vendor' frame, offshore groups employ a 'same-status collaborative partner' frame to explain their own roles (Ravishankar, 2014). A frame broadly refers to a particular 'schemata of interpretation' (Goffman, 1974, pp.21). It follows that for effective collaboration between two groups some form of alignment of disparate frames or interpretations may be required. Although there are some scattered references to frame alignment within the broader literature on sourcing, much of it involves framing work directed at clients by mainstream IT-BPO firms (Cohen \& El-Sawad 2007; Ravishankar et al., 2010; Ravishankar et al., 2013; Koppman et al., 2013). Empirical research on ImS ventures and on the process of aligning community and venture framings is scarce. Applying Snow et al.'s (1986, pp. 464) conceptualization of framing work to the community-ImS venture relationship, frame alignment can be viewed as the linkage of the community's and the ImS venture's interpretive orientations such that some set of community's interests, values and beliefs and the ImS venture's goals and ideologies become complementary and congruent. In this paper, through an ethnographic study conducted in India, we explore an ImS venture's framing work directed at the local community. We argue that frame alignment plays a crucial role in the establishment and operational continuity of ImS ventures. Further, we develop an inductive model, which explains the process through which competing frames get aligned. 


\section{FRAMES, FRAMING AND FRAME ALIGNMENT}

Erving Goffman's (1974) ideas on the frame concept in his insightful work Frame Analysis have been widely used by scholars in various disciplines to understand how individuals and organized groups (e.g., companies, teams, political movements etc.), 'share and negotiate interpretations of the world' (Mazmanian, 2013). As Goffman (1974, pp.21) suggests, actors invoke or activate a frame or a schemata of interpretation to make sense of social situations and events. The invoked frames thus give meaning to what, from an ontological perspective, could be classed as events lacking in meaning. Frames not only provide meaning, but also shape actors' responses. To use Bateson's (1972) example, the response of a monkey to the 'push' of another monkey would depend on whether a 'frame of play' or a 'frame of fighting' was employed to assess the pushing action. More recently, Leonardi (2011) examined how engineers from different departments framed a technological artefact - a car crash simulator - differently. These 'framing' differences eventually influenced the engineers' interpretation of what the technological artefact meant and the problems they were supposed to solve with it. Essentially, these engineers used language and other symbolic gestures to reinforce existing frames or called forth new frames to understand and interpret the artefact in question. Framing, the verb form, is seen as the very process of meaning making and implies 'agency and contention at the level of reality construction' (Benford \& Snow, 2000, pp. 614). Thus, Goffman (1974) refers to framing as the purposive act of invoking new frames or/and reinforcing existing frames (also see Cornelissen \& Werner, 2014). For effective collaboration between and across groups, some degree of frame alignment may be necessary to ensure broadly similar interpretations of social realities (Snow et al. 1986).

In general, organized groups are faced with the daunting task of gaining and maintaining the support of a multitude of audiences. Very often, there is a clear conflict between how audiences view the actions of a focal group and how the group itself wants its actions to be interpreted by the audience. The sociology literature has argued persuasively that such predicaments could be a result of incongruent framings of the audience and the focal group (Goffman, 1974; Snow et al., 1986). In order to minimize such misalignments and to strengthen their cognitive hold on the audience, groups may resort to frame alignment strategies. Research on the 
emergence of social movements has vividly demonstrated how frame alignment strategies can be used to recruit members for collective action. The success of many of these movements has often been explained as an outcome of the strategic use of frame alignment (Snow et al., 1986; Cress \& Snow, 2003; Snow \& Byrd, 2007). Snow et al. (1986) outlined four different alignment mechanisms, which also figure prominently in the empirical sections of this paper.

First, although two groups share similar interpretive orientations (or frames) and stand to benefit from knowing each other, they may remain in the dark about each other's existence and intentions. For instance, electric-car manufacturers and electric-car enthusiasts may share a passion for environmentally friendly cars, but remain unaware of each other's work. Through frame bridging, the 'ideologically congruent, but structurally disconnected frames' (Snow et al., 1986) of two such groups can be bridged. The internet is increasingly seen as a popular medium for transmitting particular ideological stances and thereby bridging disconnected frames. For instance, organizations use activist networks such as avaaz.org and change.org as conduits to reach out to prospective adherents with similar ideological bases. Second, for some groups, survival can be strongly linked to their audience continuing to hold a certain belief as important. Such groups may have to periodically re-invoke and elevate those beliefs to salience by amplifying their relevance to their audience's life. This process is referred to as frame amplification. For instance, climate change activists frequently amplify the arguable notion that global warming is underway and that the dangers are imminent. If this belief falls into disuse, the audience - the international community - may stop viewing climate change as an issue worth fighting for.

Third, a group may not yet hold the values and beliefs highly regarded by their audience. In such a scenario, they may have to extend their cognitive frameworks and show commitment to the values and beliefs that appeal to their audience. Such frame extensions are used either to identify with an audience of primary importance, or to expand the group's market reach. McDonald's adoption of a kosher menu in Israel and halal menu in Islamic nations can be viewed as good illustrations of frame extensions at work. Extension of frames may also possibly lead to disputes within an organization if internal participants see them as dilutions of core value systems (Benford, 1993; Benford \& Snow, 2000). Finally, the values and beliefs espoused by 
a group could openly contradict the audience's belief and value systems. Such instances call for what Snow et al. (1986) term as frame transformations. An organization could use frame transformation to inject new cultural material into the audience's existing mental models. The transformed values and beliefs enable the audience to view events in a completely different light - essentially transforming their frame through 'a systematic alteration' (Goffman, 1974, pp. 45). For instance, Hamas, the Palestinian resistance movement, seems to have successfully transformed a 'sin frame' into a 'martyrdom frame' to legitimize the act of suicide bombing (Snow \& Byrd, 2007). Table 1 is a summary of the four frame alignment mechanisms.

\begin{tabular}{|c|c|}
\hline $\begin{array}{c}\text { Frame alignment mechanisms } \\
\text { (Snow et al., 1986) } \\
\text { Frame bridging }\end{array}$ & $\begin{array}{r}\text { Purpose } \\
\text { to better connect with an as-yet unfamiliar } \\
\text { audience }\end{array}$ \\
\hline Frame amplification & $\begin{array}{r}\text { to reinforce and magnify the importance of } \\
\text { certain ideas }\end{array}$ \\
\hline Frame extension & $\begin{array}{c}\text { to demonstrate commitment to the values } \\
\text { and beliefs that already appeal to the } \\
\text { audience }\end{array}$ \\
\hline Frame transformation & $\begin{array}{c}\text { to get the audience to interpret situations } \\
\text { and events in a completely different light }\end{array}$ \\
\hline
\end{tabular}

Table 1: Frame alignment mechanisms

\section{IMPACT SOURCING, FRAMES AND FRAME ALIGNMENT}

The hiring and training of individuals from marginalized communities to take on digitally enabled work is a relatively new phenomenon. Although we use the term 'impact sourcing' (ImS) in this paper (Accenture, 2012; Monitor, 2011; Carmel et al. 2013), it must be acknowledged that a clear consensus is yet to emerge in the literature on what this phenomenon should be called. Empirical research is still in its infant stages and accordingly, many other labels are in contention: 'social outsourcing' (Heeks \& Arun, 2010), 'microwork' (Gino \& Staats, 2012), 'rural sourcing' (Lacity et al., 2010; Sandeep and Ravishankar, 2013), 'social IT sourcing' (Madon \& Sharanappa, 2013; Sandeep et al., 2013) and 'digital jobs' (Rockefeller, 2013). 
Recent articles in the business press have reinforced the value proposition of the ImS model for clients (Accenture, 2012) and its potential to create sustainable livelihoods, especially in developing countries (Monitor, 2011). A small number of academic articles have begun analyzing the role of ImS ventures in promoting developmental goals (Madon \& Sharanappa, 2013) and their impact on the lives of rural employees (Heeks \& Arun, 2010). In general, the growing optimism about the potential impact (i.e., livelihood creation for marginalized communities) of the model has steered attention away from the more fundamental issue of building relationships with local communities. As a point of departure, this paper in addressing the question 'how do companies frame their ImS ventures to the local community?' demonstrates the difficulties ImS ventures face in influencing and working with local communities.

While they do not explicitly use the 'framing' lens, some recent literature provides insights into the framing work undertaken by more traditional IT-BPO ventures to influence both clients and local communities (Cohen \& El-Sawad, 2007; Ravishankar et al., 2010; Koppman et al., 2013; Ravishankar et al., 2013). For instance, Koppman et al. (2013) examined how an IT-BPO company framed their low status vis-à-vis their clients as a product of cultural differences and simultaneously used various framing strategies to improve their status. Ravishankar et al. (2010) showed how the framing of certain organizational practices in vendor firms was part of a deliberate effort to 'look', 'talk' and 'behave' like clients. In a more recent study, Ravishankar et al. (2013) argued that employees framed their impression management tactics as best practices in order to navigate complex relationships with Western clients. These examples broadly point to how IT-BPO companies frame their reality with a broad intent to align with their client's expectations. The mainstream media also offers some illustrative examples of IT-BPO ventures' framing work, which targets urban communities. These companies, particularly in their early days, faced dissent from their local communities, which stood opposed on cultural grounds. The highly acclaimed documentary feature, The Other Side of Outsourcing (Friedman, 2004), for instance, captures some of these dynamics by portraying the framing work of IT-BPO companies and juxtaposing it against the perspectives of community participants such as civil society organizations and family members of IT-BPO employees. In this feature, IT-BPO entrepreneurs can be seen framing the outsourcing phenomenon as a necessary tool for the nation's economic prospects. 
ImS ventures also face similar challenges while working with marginalized local communities. However, there are some important differences between 'mainstream' IT-BPO companies and ImS ventures. IT-BPO companies are largely insulated from the concerns of the community that lies outside the physical boundaries of their organization (see Ravishankar et al., 2013, pp.8). The penalties for not appeasing the 'general public' may be minimal and companies may resort to more symbolic corporate social responsibility initiatives (see Porter \& Kramer, 2011). The ImS model makes an important departure here. Since their primary objective is to work with the community, not having the community by their side could potentially prove to be the single-most important reason for a failed business. Local communities can harm the sustainability of the model in a decisive way if they choose to strongly oppose ImS ventures. As Seelos et al. (2010) note in a broader context, social enterprises can find it particularly difficult to operate in communities that are not receptive to new ideas. Having very little exposure to the outside world, some communities can be locked into 'inefficient practices' and may find it difficult to change long standing norms and practices. Additionally, when they have long histories of exploitation and marginalization, communities may adopt a distrustful and cynical approach to well-meaning 'interventions'. For instance, Thompson and Macmillan (2010) report on the extreme reluctance of women in a local community in an impoverished South African township to take up jobs (which they badly needed) offered to them in a cookie factory started by a social enterprise. Power asymmetries and gendered relationships caused other problems for this social enterprise. Managers had to also deal with opposition from powerful male community members who feared losing their influence if women in the community became self-reliant. Although this example is not directly related to the IT-BPO sector, it reinforces the point that local communities need not respond positively to an ImS venture. In the following sections, we employ concepts from the frame alignment literature and draw on an ethnographic study to analyze the framing strategies employed by an Indian ImS venture.

\section{EMPIRICAL CONTEXT}

Origins of the ImS venture 
Rajiv $^{2}$ had an established career in one of India's largest IT-BPO firms. He had led several multi-million dollar projects with large western client organizations in his fifteen years of employment in the sector. However, he had his share of existential struggles.

Over a period of time my career hit a plateau - I asked myself, now what? I no more felt so thrilled about the fact that I have to go to work another day to work my ass off for this company which is half way across the world so that they can be happy about the million we collected for them every week. I was deeply dissatisfied with what I did, but what do I do? I asked myself...

Rajiv had been travelling to the Himalayas every now and then to take a break from corporate life. Over a period of time, he had developed a sense of belonging to the place. He and his long-time associate, Sanjiv, were moved by the day to day struggles of the rural communities in this region. They got in touch with a local not-for-profit organization, Rural Lives (RL), to learn more about the area and its people. RL supported and implemented social-welfare programmes for historically disadvantaged communities and had nearly three decades of experience of working with rural, marginalized communities in this area. Over this period it had (i) helped rural women acquire new livelihood skills such as embroidery and craft making, (ii) helped communities conserve natural resources (iii) built and managed a hospital and a primary school and (iv) provided financial assistance to poor communities through micro loans. RL also employed about 150 people from the local communities to manage their projects.

Initially, Rajiv and Sanjiv considered designing and implementing 'interventions' in areas such as public health, agriculture and education. Their interactions with $\mathrm{RL}$ told them that people in this region had very few mainstream employment opportunities. As a result, there was widespread migration of youth to nearby cities. They also learnt that nearly $25 \%$ of the workforce in major IT-BPOs in the nearest city actually comprised of people from this region. This prompted both of them to explore the possibility of establishing an IT-BPO company in this remote rural region to provide employment opportunities locally. In 2009, the idea of establishing Impact Venture (IV), an IT-BPO for-profit social enterprise began to

\footnotetext{
${ }^{2}$ Names of people, places and companies have been anonymized.
} 
take shape. When they discussed this idea with their friends, and later with potential investors - they were scoffed at and called 'idiots' for even trying such an idea. Their well-wishers associated rural India with infrastructure problems such as lack of internet connectivity, power and skilled human resources. They warned the two tobe entrepreneurs against such a venture. However, after producing a detailed plan about the sustainability and scalability of their business model, Rajiv and Sanjiv managed to convince a social venture capital firm to fund IV. The first IV centre was established in 2009 in a village in the Himalayan region. Now, there are five such centres employing close to 350 people (see Figure 1 below). In each centre, people from the community are hired and trained to work on IT-enabled business processes. Women constitute around $65 \%$ of the IV workforce.

IV serves both national and international clients in areas such as publishing, e-commerce, web services, insurance, banking and finance and back office support. IV also claims to commit a significant proportion of their profits towards 'development' of the community. IV is supported by $\mathrm{RL}$, the local organization alluded to earlier. RL helps IV in developing closer links with the community, managing operations, and in the hiring and training of new recruits. In each of the five villages, where the centres are located, IV has established an advisory committee. The committee consists of influential leaders from the community and representatives from IV and RL. The primary function of the committee, which convenes once every month, is to discuss IV's plans and activities and resolve any 'problems' experienced by the community because of IV's operations.

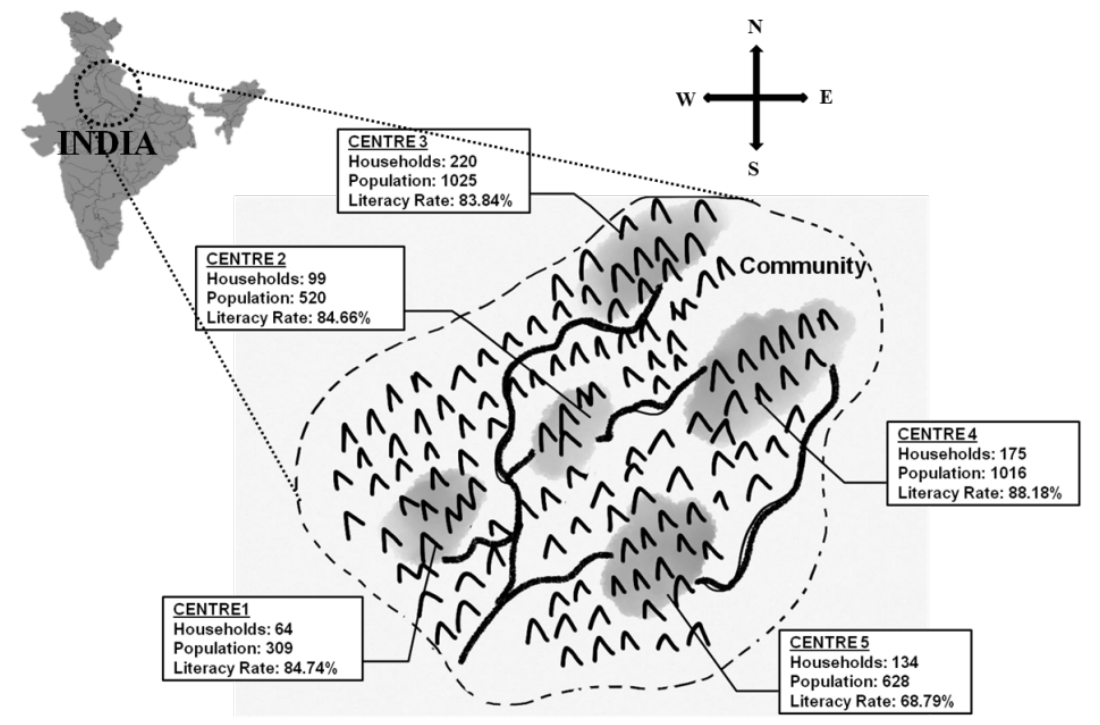

Figure 1: Overview of the community 


\section{Operational context of the ImS venture}

A six hour train journey from the nearest city and a further three hour road trip through winding mountain country brings one to the areas of IV's operation. IV operates in five villages in this region each with an average population of 700 . In this paper we use the term 'community' or 'local community' to refer to the people living in this region (depicted in Figure 1 above). Administratively, the community lies within the boundaries of a North Indian state. This particular state government gives very little support to private ImS ventures unlike some other states in the country (e.g., Karnataka), which offer start-up grants to ImS entrepreneurs. The community is predominantly Hindu (both upper-caste and lower-caste). Sikhs and Buddhists make up the rest of the community. $51 \%$ of this community are women. Two main languages are spoken here: (a) the state's own official language and (b) Hindi.

This part of India is known to be poor and under-developed with few opportunities for gainful employment. During our ethnographic fieldwork we found that the economy of this community was mainly centred on agrarian activities. It was common for the community's youth to migrate to nearby cities in search of better job opportunities. Significantly, this mobility was not enjoyed by women. They were expected to 'work the land' and get involved in day to day domestic activities. The older members of the community held gendered and feudal world-views. They tried hard to impose their views on matters such as 'mixing of boys and girls' and 'what young people must wear', which according to them were issues of great moral significance. The younger members resisted (with varying degrees of success) this 'interference in their personal affairs'. We saw that the caste system and a patriarchal way of life heavily influenced and regulated social order in the community. Inter-caste marriages were frowned upon and the shadow of caste hung heavily over every day interactions. Families appeared to be under tremendous pressure to abide by social codes related to caste and patriarchy, which according to our informants were passed on through generations. People who transgressed these norms were penalized and in extreme cases ostracized from the community (for in-depth and insightful social-anthropological accounts of village life in India, see Bhyrappa, 2003; Breman, 2007; Jodhka, 2014; Srinivas, 1976).

We also found that there were very few organizations operating in these regions, let alone IT-BPO companies, which are seen as show-pieces of the modern 
and post-liberalization India. While the idea of working in a 'city-like' office was alluring for the youngsters in this community, the final decision regarding their career choice was rarely in their hands; especially for women, whose gendered roles restricted them to preordained tasks. Operating an ImS venture in such a community was clearly not a straightforward task. Apart from the problem of finding qualified, employees, running an ImS venture also meant creating a new social space that brought together people from different castes, altering gender roles and changing the underlying social fabric of the community in a very fundamental way. The next section discusses how we went about understanding IV's efforts to establish and operate an ImS venture in this community.

\section{RESEARCH METHODS}

IV represents an extreme case of an ImS venture because of its operational context - it is based in a remote rural community in the Himalayan region. To understand in-depth the social worlds of IV and the community, we adopted an interpretive ethnography approach (Myers, 1999; Ravishankar, 2013). An interpretive approach allows researchers to understand the social and cultural worlds of human actors in their contextual setting (Ravishankar, 2013). In doing so, the researcher stands to gain unique insights into the phenomenon being observed through an understanding of different cultural symbols and meanings socially constructed by human actors.

Researchers adopting an ethnographic approach spend intensive hours in 'the field' observing social life (Van Maanen, 1979; Ravishankar, 2013). Data is gathered via various means such as participant and non-participant observation, surveys and interviews. Fieldwork happens in an organic manner with the researcher going about exploring the field looking for and understanding the common denominators of cultural and social lives through the accounts of human actors. Although we did not have a pre-conceived framework to analyze the social worlds of actors, we employed a broad 'sensitizing device' (see Walsham, 1993) in the form of the framing literature (Goffman, 1974; Snow et al., 1986; Benford \& Snow, 2000) to guide our fieldwork. We expected various alignment mechanisms to shape IV's work in the local community. However, we did not hypothesize any specific processes or relationships. 


\section{Data sources}

Our research is primarily informed by empirical material collected over a sixmonth ethnographic fieldwork (from March 2013 to August 2013) of IV and the community within which it operates. We collected data through open-ended interviews and non-participant observations. We also reviewed secondary sources such as company blogs, websites and social media outlets to better understand IV's work and strategies. Table 2 below gives an overview of our fieldwork and details the different groups of informants. In the analysis section that follows, we refer to three broad categories of informants: (i) IV informant, (ii) Community informant and (iii) RL informant.

\begin{tabular}{|l|c|c|c|}
\hline \multicolumn{1}{|c}{ Category of informant } & $\begin{array}{c}\text { Number of } \\
\text { male } \\
\text { informants }\end{array}$ & $\begin{array}{c}\text { Number of } \\
\text { female } \\
\text { informants }\end{array}$ & $\begin{array}{c}\text { Total } \\
\text { number of } \\
\text { informants }\end{array}$ \\
\hline IV senior management & 4 & 0 & 4 \\
\hline IV middle management & 8 & 0 & 8 \\
\hline IV employees & 14 & 11 & 25 \\
\hline Community informants & 9 & 6 & 3 \\
\hline RL informants & 3 & 0 & $\mathbf{5 5}$ \\
\hline Total & $\mathbf{3 8}$ & $\mathbf{1 7}$ & \\
\hline
\end{tabular}

Table 2: Overview of fieldwork

One of us conducted intensive ethnographic fieldwork. This included him 'hanging out' with IV employees, striking up conversations with community informants in local tea stalls and eateries, attending IV team meetings and observing their 'daily team huddles'. He conducted unstructured and open-ended interviews with IV employees and community members. The interviews lasted anywhere between 15 minutes to more than two hours. Interviews with IV employees and community informants were conducted in Hindi, whereas interviews with IV senior and middle management were conducted in English. The first author spoke both Hindi and English fluently and was therefore able to manage the interviews with reasonable confidence. These interviews were recorded, transcribed and translated (when needed). He also had extended hours of interactions with Sanjiv, the CEO of IV, while travelling with him on train and car journeys. Many of these in-depth conversations continued late into 
the night. He interacted with locally recruited IV employees in the guest houses where he was lodged. He also accompanied IV managers to public community meetings and observed the interactions during such meetings. These meetings were usually called to resolve disputes between IV and community members and to update the community about IV's operations. The community meetings were called for either by the village advisory committee referred to earlier or by the gram sabha ${ }^{3}$, the local village council. The advisory committee membership was drawn from both the community and IV management whereas the gram sabha comprised entirely of elected representatives from the community. Detailed notes about community meetings and conversations with informants were made at the end of each day of fieldwork.

\section{Data analysis}

The data analysis comprised of several stages. In the first stage a database was built comprising of (1) empirical material relating to IV's interactions with the community as described by the informants to the field researcher, (2) empirical material collected during observations of IV's meetings with community leaders and (3) field notes relating to the interviews and conversations with informants in the community. In the second stage, we conducted a line-by-line analysis of this database and identified raw empirical data relating to how IV was attempting to manage the relationship with the community. This raw data were synthesized into first-order themes using an open coding process (Strauss and Corbin, 1998). In the third stage we looked for relationships between first-order themes and grouped them into four second order themes: (1) IV's commitment to the progress of the community (2) IV's self-positioning as an integral part of the community (3) IV's claim of bringing material benefits for the community and (4) IV's claim of being an equal opportunity provider.

At this point, it was evident that these themes were specific cognitive interpretations of IV's actions as perceived by all categories of informants. In light of the literature on frames, we re-coded the above four second-order themes respectively, in framing terms, as follows: (1) Progress frame (2) Family frame (3)

\footnotetext{
${ }^{3}$ The gram sabha is the smallest administrative unit in rural India. Members of the gram sabha are elected into office by the community.
} 
Material-benefit frame and (4) Egalitarianism frame. Further, we found that these frames were deployed either reactively or proactively, i.e. either in response to the community's opposition (in which case they were classified as 'reactive') or in anticipation of the community's opposition (in which case they were classified as 'proactive'). Next, drawing on the frame alignment literature, we explored the underlying processes of achieving alignment. Going back and forth between the literature on frame alignment and the empirical material, we found evidence of four strategic frame alignment processes, which also corresponded closely with Snow et al.'s (1986) conceptualization of frame bridging, frame transformation, frame extension and frame amplification. Also evident in our data were several instances of counter-framings both by community informants and IV informants. Following Ryan (1991), we categorised these instances as 'framing contests'. We then synthesized these findings in the form of a process model of competing frames and their alignment. We revisited our empirical material and travelled back and forth iteratively from the data to the literature on frame alignment until there was a reasonable fit between data, theory and model and no further iterations seemed valuable.

\section{ANALYSIS}

Permeating the empirical material were several striking illustrations of the framing work undertaken by IV. As noted above, one of the authors directly witnessed the framing work undertaken by IV managers during their meetings with the community. Also, during interviews IV informants candidly elaborated on their framing strategies. Further, informal interviews and conversations with community informants helped us gain a deeper understanding of their response to IV's framings. Broadly, IV engaged in framing either proactively, with foresight, or reactively, to counter the community's counter framings. Table 3 below summarizes these findings. IV informants typically invoked four frames (see Table 3) to facilitate the establishment and smooth operations of their ImS venture. In the following sub-sections we analyze IV's framing work.

\begin{tabular}{ccccc}
$\begin{array}{c}\text { Frame } \\
\text { invoked by } \\
\text { IV }\end{array}$ & $\begin{array}{c}\text { Framing } \\
\text { type }\end{array}$ & $\begin{array}{c}\text { Frame } \\
\text { characteristics }\end{array}$ & $\begin{array}{c}\text { Frame } \\
\text { Alignment } \\
\text { mechanism } \\
\text { used }\end{array}$ & $\begin{array}{c}\text { Change in } \\
\text { community's } \\
\text { perception of IV }\end{array}$ \\
\hline
\end{tabular}




\begin{tabular}{|c|c|c|c|c|}
\hline $\begin{array}{l}\text { Progress } \\
\text { frame }\end{array}$ & Proactive & $\begin{array}{l}\text { Bridges the } \\
\text { disconnect between } \\
\text { IV and the } \\
\text { community by } \\
\text { invoking the idea of } \\
\text { progress. }\end{array}$ & Frame bridging & $\begin{array}{l}\text { From being a } \\
\text { unknown private } \\
\text { city firm to that of } \\
\text { a welfare } \\
\text { providing, } \\
\text { trustworthy } \\
\text { organization. }\end{array}$ \\
\hline $\begin{array}{l}\text { Family } \\
\text { frame }\end{array}$ & Reactive & $\begin{array}{l}\text { Extends IV's role. } \\
\text { Positions IV as a } \\
\text { family member } \\
\text { rather than as an } \\
\text { outsider. }\end{array}$ & $\begin{array}{l}\text { Frame } \\
\text { extension }\end{array}$ & $\begin{array}{l}\text { From being } \\
\text { viewed as 'city } \\
\text { folks' to being } \\
\text { considered as } \\
\text { members of the } \\
\text { community's } \\
\text { family. }\end{array}$ \\
\hline $\begin{array}{l}\text { Material- } \\
\text { benefit } \\
\text { frame }\end{array}$ & Proactive & $\begin{array}{l}\text { Transforms how the } \\
\text { notion of liberal } \\
\text { values is framed by } \\
\text { the community. }\end{array}$ & $\begin{array}{l}\text { Frame } \\
\text { transformation }\end{array}$ & $\begin{array}{l}\text { From being } \\
\text { viewed as an } \\
\text { agent of } \\
\text { undesirable } \\
\text { cultural change to } \\
\text { being seen as a } \\
\text { benefactor. }\end{array}$ \\
\hline $\begin{array}{l}\text { Egalitarian- } \\
\text { ism frame }\end{array}$ & Reactive & $\begin{array}{l}\text { Amplifies the belief } \\
\text { that IV is not } \\
\text { discriminating and } \\
\text { that everybody in } \\
\text { the community } \\
\text { benefits from the } \\
\text { ImS model. }\end{array}$ & $\begin{array}{l}\text { Frame } \\
\text { amplification }\end{array}$ & $\begin{array}{l}\text { From an entity that } \\
\text { is viewed as } \\
\text { partial, to an entity } \\
\text { that is seen as } \\
\text { being deeply } \\
\text { concerned about } \\
\text { the well-being of } \\
\text { the entire } \\
\text { community. }\end{array}$ \\
\hline
\end{tabular}

Table 3: Frames, frame characteristics and frame alignment mechanisms

\section{Frame bridging}

The community had limited opportunities for gainful employment. Very few people owned substantial agricultural land. The mostly poor families found it almost impossible to improve their material conditions. They either had to work their small tracts of land or take up 'dead-end' jobs in fruit-processing factories or mills nearby. Invariably, the youth in the community, especially men migrated to cities to look for better livelihood opportunities; the women stayed at home to help in domestic work.

We did not have other options before. For a man, the only respectable job around here is to join the army. Or some job in the city. That works out only if you have some education else you will be 
stuck in a low paying job. It is not worth it. Even if I get half that salary here in my village, I would be happy. (Community informant)

The community preferred living and working (even with lower wages) in their own villages over migrating to the city. The founders of IV believed that they understood these troubles of the community. They wanted to provide 'respectable' job opportunities to the young people in the community. However, the community did not know what IV was up to and what its intentions were. More crucially, IV did not have the trust and respect of the community. Also, prolonged marginalization from mainstream development and the hollow election-time promises by politicians made the community doubt any and every well-meaning offer of assistance. IV fit the description of a typical 'do-gooder' wanting to change the community's prospects. Thus, there was a fundamental disconnect between the community and IV (depicted in Figure 2 below).

$\mathrm{RL}$ have worked in these areas for as long as I can remember. They have been dedicated to improving the lives and livelihoods of our people. But IV, we had never heard of them. We thought they were just another company from the city...people who come here with big plans! (Community informant)

$\mathrm{RL}$ had considerable respect and trust within the community. However, IV was new to the community, and the community members were sceptical of IV's intentions. They framed IV as just another private enterprise from the big city.

Through our interactions with $\mathrm{RL}$, we knew that we won't exactly be welcomed by the community. There is a certain rhythm to the life on the hills and it takes a while to understand its patterns. We were very clear right from the beginning that we had to work with a local organization such as RL who understood this rhythm. (Sanjiv, CEO of IV)

The founders of IV benefitted immensely from partnering with $R L$ in what was a culturally unfamiliar territory. Given its deep knowledge of local values and traditions, $\mathrm{RL}$ played an important role in helping IV overcome their legitimacy deficit. They introduced IV's founders to influential community members, encouraged the community to apply for jobs at IV and did a door-to-door 'campaign' in the community 
during which they explained the ImS business model and its benefits. As Tracey et al. (2011) note, one way for new social businesses to gain legitimacy is to align with highly established actors in their field, such as RL in this case.

First, we call for a meeting in the village. In the meeting we introduce IV and talk about what IV is here to do. We request the community to give the same kind of support which they have given us. We ask them to trust IV like they trust us. (RL informant describing how they support the establishment of a new IV centre)

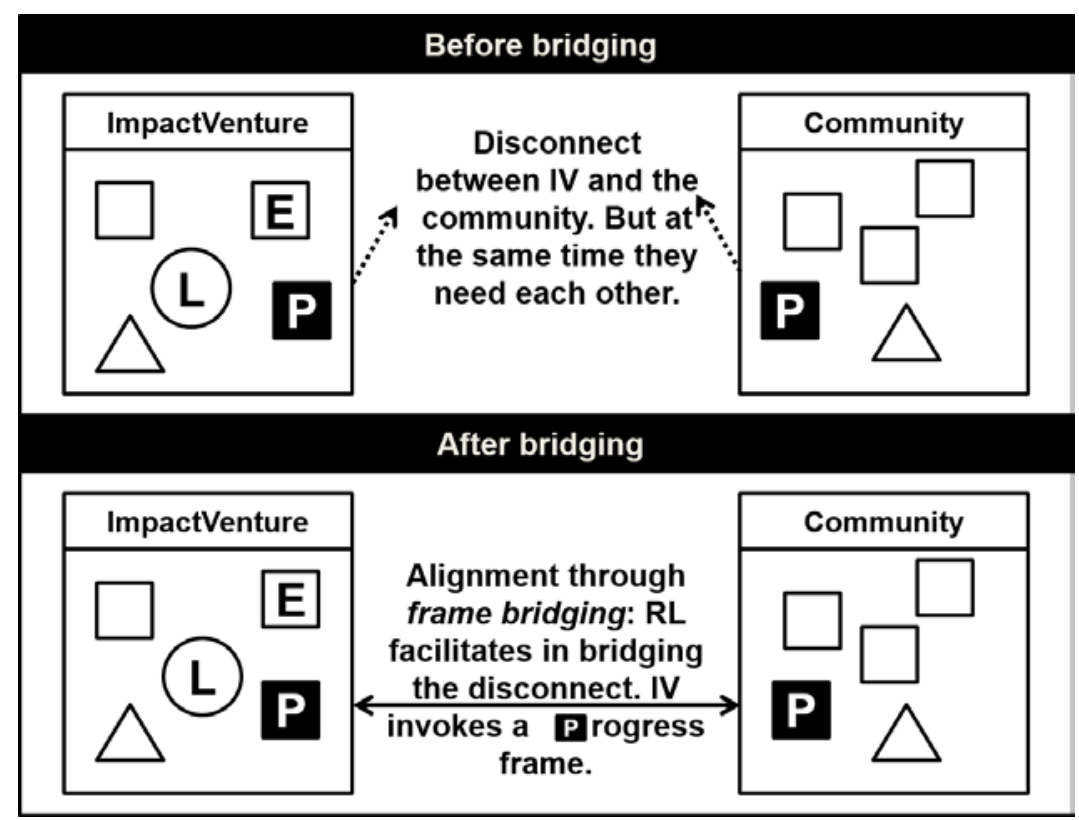

Figure $2^{4}$ : Frame bridging

RL essentially acted as a conduit between IV and the community by opening a channel of communication. Their efforts helped IV and the community to get to know one another. Crucially, they helped IV gain some much needed trust and respect within the community. Also noticeable was the proactive work of IV managers. They spoke about their vision of providing jobs and employment, words aimed at bridging their urban world with the rural realities of the community.

Initial meetings with the community are very important. This is where we build confidence in them about who we are and what we do. We try our

\footnotetext{
4 Figures 2, 3, 4, and 5 depict how IV's framing work led to alignment of disparate frames. IV's and the community's framings are represented by geometrical shapes. Each figure also highlights the invoked framings in bold.
} 
best to make them understand that we are here to provide jobs for their children at their doorstep. And that we are here only to contribute and not to take anything from them. We seek their cooperation so that we can work effectively toward the progress of their community. (IV informant)

In other words, IV framed their work and their activities as bringing 'progress' through job creation. This was something the community could relate to deeply. 'Progress' seemed to be the answer to the most pressing problems - scarcity of jobs and an uncertain future for the youth - facing the community. We can term this frame as a progress frame. The idea of 'progress' clearly appealed to the community. The progress frame essentially connected the two worlds by helping the community to take notice of IV's 'good' intentions. Many in the local community began to trust IV and offered them support (depicted in Figure 2 above). The change brought about by IV's framings is illustrated in the following quote.

On Sundays when the office [IV's centre] is closed, there is a silence on this road. The chatter of our children [who work at IV] is missing. It is a reminder of how it used to be before IV came here! I have no regrets our kids can now get a respectable job right in their village. (Community informant)

\section{Frame extension}

The entire senior management and most of the middle management at IV had no roots in the local community. As a result the community found it difficult to identify with IV. They regarded IV as outsiders and referred to them somewhat pejoratively as 'Delhi-walein' (people from the city of New Delhi). After regularly running into opposition from the community for being 'outsiders', IV realized that the idea of 'family' commanded high currency in the community - an aspect which they hadn't given much thought to earlier. The community prided itself on being a 'family' and this metaphor guided its everyday affairs. For instance, it was considered normal and acceptable to interfere in the personal affairs of other people on the basis that the prestige of the 'community family' was at stake. IV managers responded to the 'outsider' framing of the community by deliberately incorporating discourses of familial values and beliefs into their vocabulary (depicted in Figure 3 below). The 
following example from our field notes best illustrates how IV tried to extend the boundaries of its relationships with the community by activating the 'family' dimension: IV required permission for a water connection from the local government. But they were being denied the connection on the premise that water was scarce and the community couldn't afford to bear the extra stress on their limited resources. However, during a community meeting, it became apparent that the issue was not really about the scarcity of water.

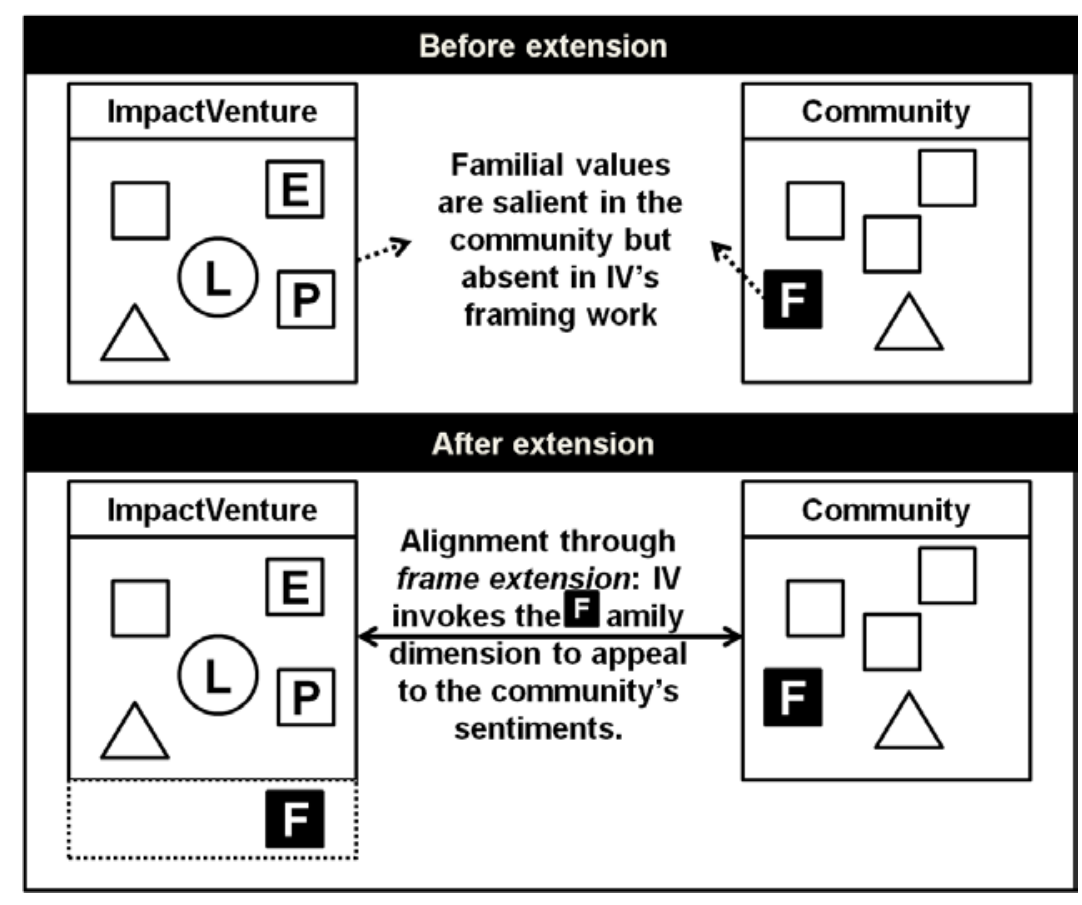

Figure 3: Frame extension

Look around you....nobody has turned up for the meeting! This is the third time that we have scheduled a meeting to discuss 'water'. They [the opposing members in the community] do not let a solution emerge. They are your antagonists. They feel that you are outsiders and they ask me why we should share our resources with you! (Community informant - president of the local government addressing the CEO of IV)

But the issue is hardly about water! There is sufficient water. The antagonists are using water as an excuse to oppose your entry into the community. They think the community will be unnecessarily burdened if we let you into our fold. I feel it is not true, but they keep saying you will 
deplete all our resources and give us nothing in return (Community informant addressing the IV CEO)

Instead of thinking of us as part of the solution, you are thinking of us as part of the problem. We are one of your own! Would you deny water to your own family member? By accepting us, the family can only become stronger. There is no point in playing a game of chess. Only if we are together as a family, can we work towards a solution (Sanjiv, CEO of IV tells the gathered members of the community)

In this illustration, by positioning their venture as belonging to the community's larger family, IV fought what they believed was an unjust decision to deny them water. In many other instances, IV informants used phrases such as 'a family stays united' and 'family members help each other out' as part of their strategy to integrate better with the community. We can term such rhetoric as a family frame - a frame which idealizes familial values and principles. Through the 'family frame', IV gave the community a new vantage point to interpret their actions. The result of this kind of framing was evident on several occasions during our fieldwork. An illustrative quote:

These two [referring to a couple of IV employees from the city] come to my shop to have dinner every day. They stopped being my customers a long time back, they are part of my household now! (Community informant)

\section{Frame transformation}

As IV brought many visible changes to the prevailing norms of 'socially acceptable' behaviour, there was resistance from a section of the community. IV managers had anticipated such a reaction.

The values which are espoused in our organization - of equality and inclusion go against the social fabric of this place. It came as no surprise to us that the community had issues with these changes. When the village elders see young people chatting on the road, wearing jeans pants and shades, dressed like movie stars, it does not go down well with them. And whenever somebody gets into trouble, we are blamed. (IV informant) 
The older members of this highly orthodox and conservative community, in particular, did not view the IV-led changes as progressive.

When I get back home from office I am tired of sitting all day in front of the computer. I like spending time by myself or just going out with my colleagues. My parents understand this, they are very supportive. But the problem is with my other elders - my grand uncle and aunt - they don't like the changes they see - they want me to be the same girl I was - helping them out with chores. (IV informant)

The older community members found many reasons to resist IV's influence and framed the liberal values espoused by IV as decadent. Some of them argued that IV's liberal values were destroying community life. They invariably associated liberal values with the 'hedonistic culture' of the city, widely publicized through Bollywood movies (the Hindi film industry). To them liberal values meant 'immoral socializing' between men and women and 'inappropriate' attire such as jeans and shades. IV was seen as an incarnation of these values and hence a 'bad' influence. The following excerpt from our field notes shows how such community members perceived IV.

A girl and a boy (from the community) who had ventured into a neighbouring town on a motorbike have met with a serious accident on their way back. Incensed community members (especially the older ones) are quick to assign blame on IV for the incident without even bothering to find out more. As we learn later, the couple had no connection to IV whatsoever. Just the act of a girl and boy 'hanging out' together is seen as representative of IV's influence on the community's youth.

Essentially, 'liberal values' meant completely different things to the two sides (depicted in Figure 4 below). For IV, liberal values meant freedom of choice, freedom of expression, social inclusion and equality. To them, the 'empowerment' of women, who constituted nearly $65 \%$ of their workforce, was something fundamental and essential. IV tried to transform the extant meaning of liberal values by proactively altering the community's perceptions. 
When girls and boys start working together, there will be changes around you and you may not like them. I can give it to you in writing that there will be ten other related issues which will follow! But please don't forget that these changes are also giving jobs to your children and brining prosperity to your community. You cannot resist change and at the same time wish that your community improves. If we take four steps towards your welfare, you should at least take one step in our favour. (IV informant, assuaging the community's concerns at a monthly advisory committee meeting. In attendance at this meeting were IV senior and middle managers, representatives from $R L$ and influential members of the community)

IV's portrayal of liberal values was centred on the material benefits dimension. During community meetings, IV managers continued to reinforce the message that liberal values meant material benefits rather than self-indulgence and immorality.

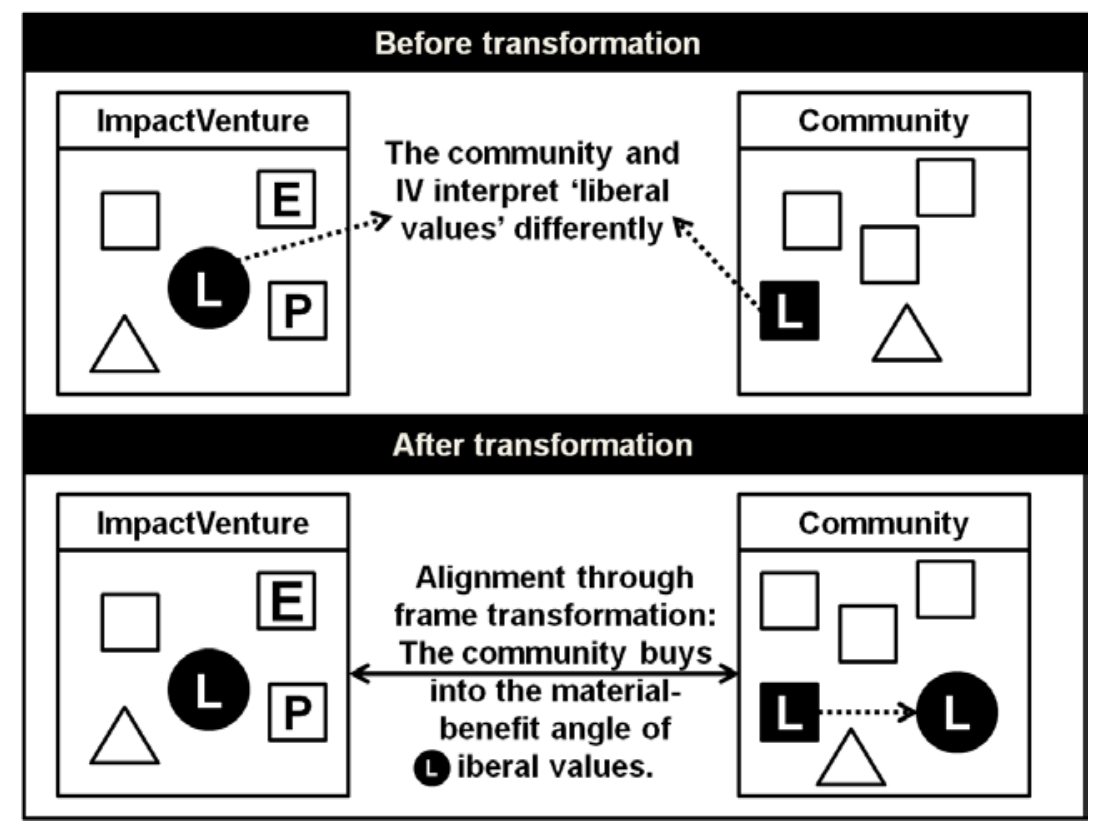

Figure 4: Frame transformation

Put differently, IV tried to transform the extant meaning of liberal values as understood by the community. We can term this kind of frame as a material-benefit frame. Using this frame, IV highlighted the benefits of accepting their version of liberal values while at the same time implicitly questioning the utility of the community's orthodox values. By and large, community informants were influenced by this new way of looking at liberal values (depicted in Figure 4 above). During the 
five years of IV's operations family incomes of the employees has increased and the local economy has also received substantial impetus due to the increase in disposable incomes of these families. Generally, IV seems to be viewed now as a 'good thing' by the community.

Like with all new things, changes will definitely be there. But you have to see what the cost of the change is. Now my daughter is independent, she has money to spend on herself and for our family. If not for her job, she would be sitting idle at home. This has of course been for the good. (Community informant, father of an IV employee)

\section{Frame amplification}

Although IV projected itself as an impartial organization and an 'equal opportunity provider', many in the community did not believe IV's claims (depicted in Figure 5 below). They complained that IV was, in fact, very 'partial'. Rajiv, IV's cofounder, explained the community's predicament with a metaphorical illustration.

Let me give you an example. When a bunch of people are in a life boat there is a sense of shared grief among them. Now suppose a chopper comes along and rescues only one of them, the grief turns to anger. Now there is a sense of shared anger in the group. And who are they angry at? The chopper - we are that chopper.

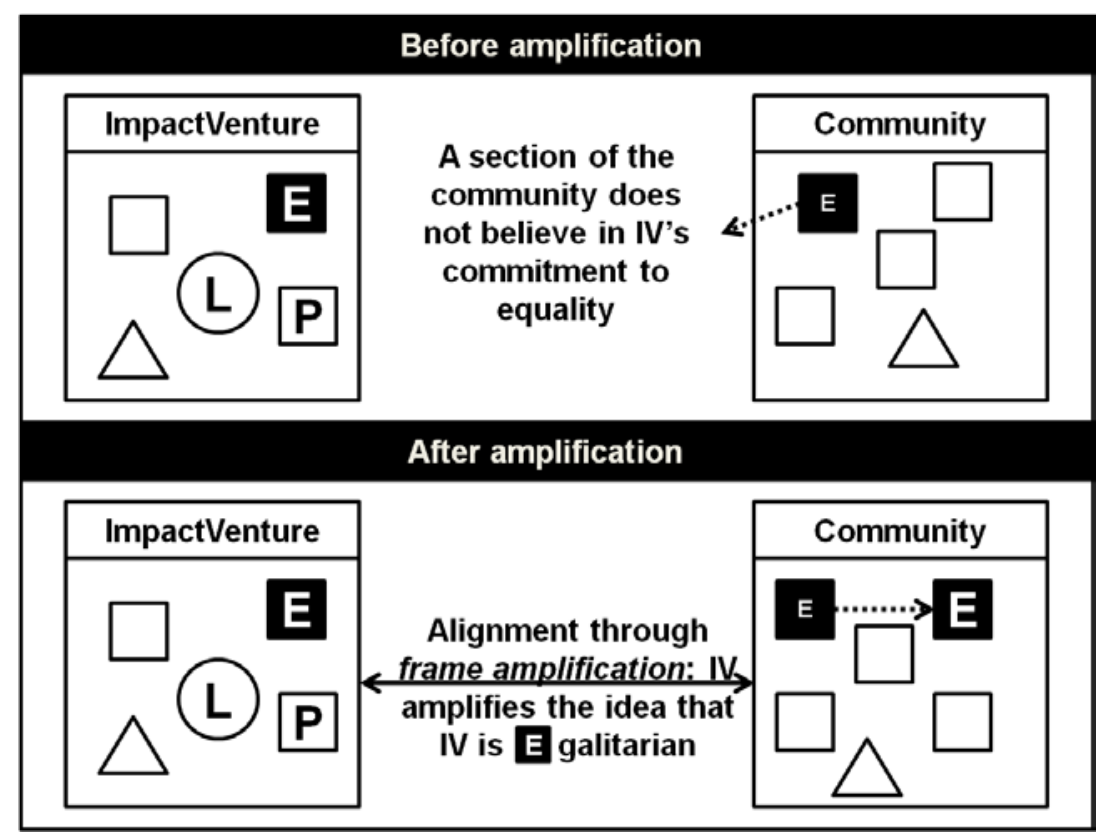

Figure 5: Frame amplification 
IV created jobs in the community. Their activities also had a positive trickle-down effect in the community- some landlords now had long term contracts with IV; shops and other commercial establishments also sprung up in the vicinity of IV's centres. But there was trouble because not everyone who applied for a job at IV got one. IV followed a 'merit' based recruitment process. One had to pass qualifying tests before getting recruited and trained by IV. In a village of around 100 families, we found that on average, only about 10 families benefitted from IV via direct employment. While the ImS model definitely improved the livelihoods of some, it also disillusioned those that did not benefit.

There are other issues which add to the community's resistance some of us benefit, while our long-time rivals in the community don't. Sometimes members of a minority caste get a job at IV and the dominant caste don't like it! (Community informant)

The perception that they were 'partial' and 'playing favourites' had serious consequences for IV. In one such instance, an IV centre was vandalized by some villagers who had failed in their job interviews. In another example, an influential member of the community stalled IV's efforts to set up a new centre as the person he hated most in the community, a landlord, stood to benefit financially from the proposed centre.

Some of these people cannot think beyond their nose! All that they think about is 'What is in it for me?' We have always been fair with the community. But, soon enough we got the message that the butter was not being spread evenly no matter how hard we tried. We did not want the community to think that we favoured particular groups or castes. More importantly, we did not want the community to lose hope in us which is why we reinforce the message: we stand for the entire community. (IV informant)

In response to the accusations of being 'partial', IV managers reiterated and amplified the message that they were in fact fair. We saw IV managers asserting over and over again during their meetings with the community that they stood for the entire community and not just for a select few (depicted in Figure 5 above). We term this discourse employed by IV managers as the egalitarianism frame. By invoking this 
frame, IV signalled and amplified their concern for the entire community. IV informants also provided other evidence of their commitment to the community's wellbeing.

We conduct English language and computer skills tutorials which is open to the entire community. Now we have shorter term contracts with our local vendors so that there is some rotation of benefits. We even counsel and train individuals who are unable to secure a job in our organization. In this way we try to ensure that everyone is happy. (IV informant)

\section{Counter-framings}

The analysis above not only details IV's proactive and reactive framing work, but also shows the community's counter-framing actions. From the accounts of our informants, it was evident that the counter-framings had more than one root. Some instances of counter-framings were purely in self-interest, but publicly packaged as a statement of concern for the community's welfare; others were linked to a genuine worry about the malign influence of 'city culture' on the community.

The fear is that IV will bring along with it the culture of the city and that this will affect the behaviour of girls and boys.

Interestingly, alongside the counter-framings were several instances of community informants working hard to re-orient the community's world view in favour of IV. They framed IV as a harbinger of 'progress' and a good thing for the 'future' of the community.

I tell those who are opposed to IV that if we cannot benefit from this model, our children can! They will get education and a respectable job right at their doorstep. But this thought is completely missing from some of our heads. Whenever people talk about IV, I tell them that it will be a great loss for us if IV decides to leave. I'm even ready to touch people's feet to stop them from blocking IV's plans (Community informant addressing a community meeting) 
The empirical material also provided evidence of a different kind of counter-framing activity within IV: The founders of IV had started the organization with a clear social mission. The explicit 'social focus', which has also been called 'social imprinting' (see Battilana et al., 2013) guided their strategies.

We have taken enough during our lifetime; it is time to give back. We must never forget why we are here. The important thing is to maintain focus on the community and its welfare. The moment we lose this focus, we become like any other business. Moreover, it is vital that we maintain a community-focus for our own survival's sake! You cannot run a business here like you run in the city. (Rajiv, co-founder of IV)

The founding members of IV were convinced that operating in marginalized communities required a hybrid (equal focus on the social and commercial dimensions) cognitive orientation. However, increasingly, the same vision was not being shared with equal gusto among other members of the senior and middle management. They disapproved the trajectory IV was taking and felt that IV must focus more on the business side of things. Internal tensions stemming from the dual focus of the business model had gone up.

I don't understand why Sanjiv has to spend his time doing other stuff. His time is precious and it better be utilized where he can have the best impact for the organization. Instead, the management bandwidth is wasted resolving petty issues in the community. (Senior manager, IV)

Some senior managers confessed that they joined IV not because of any 'calling' to 'do-good'. They did not fully comprehend the 'social' frame of the ImS model and hoped that the 'business' frame would become more prominent in IV. Sanjiv, the CEO of IV, saw it as a problem of getting the 'right' people into the company.

Of course it is a major aspect we look into when we are recruiting. But it is very difficult to judge you know. They will put on a social mask during the interview process. We have grown smarter through our experience though. We take interviews for middle and senior management positions in the areas of our operation in rural 
Himalayas. After a week of staying in the rugged terrain, their true colours usually come out, and they get a clear sense of what is in store for them.

Overall, IV has been successful in operating their ImS venture despite the presence of counter-framings. At the end of our six-month fieldwork, IV's centres continued to serve both national and international clients and also made modest profits.

\section{DISCUSSION}

The experience of IV suggests that it may be simplistic to characterize communities as passive recipients of an ImS venture's framing work. Indeed, actions of framing and frame construction to influence a community audience can be a heavily contested process (Goffman, 1974; Benford \& Snow, 2000) involving a tense struggle to reach a shared understanding of social reality. Thus, the conflicting cognitive worlds of an ImS venture and the local community can lead to what Ryan (1991) has called framing contests. On the one side of such framing contests are marginalized communities that are extremely wary of ImS ventures' offers of assistance. Such communities tend to take extremely cynical positions and may harbour and spread ideas detrimental to the sustainability of an ImS model. In our case, the community's perspectives and framings (see Columns 1 and 2, Table 4 below) have seriously tested IV's resilience and commitment to their 'sociallyconscientious' business model.

\begin{tabular}{|c|c|c|c|}
$\begin{array}{c}\text { Community's } \\
\text { viewpoint of } \\
\text { IV }\end{array}$ & $\begin{array}{c}\text { Community's } \\
\text { framing }\end{array}$ & $\begin{array}{c}\text { IV's } \\
\text { framing }\end{array}$ & $\begin{array}{c}\text { Altered viewpoint } \\
\text { of IV (held by the } \\
\text { community) }\end{array}$ \\
$\begin{array}{c}\text { IV cannot be } \\
\text { trusted as } \\
\text { they are not } \\
\text { known to us }\end{array}$ & $\begin{array}{c}\text { Unknown private } \\
\text { enterprise frame }\end{array}$ & Progress frame & $\begin{array}{c}\text { IV can be trusted; } \\
\text { they are here to } \\
\text { provide jobs and to } \\
\text { help the community } \\
\text { progress }\end{array}$ \\
\hline $\begin{array}{c}\text { Cannot share } \\
\text { our resources } \\
\text { with IV. They } \\
\text { don't belong } \\
\text { here }\end{array}$ & Outsider frame & Family Frame & $\begin{array}{c}\text { IV is a member of } \\
\text { the extended family }\end{array}$ \\
\hline
\end{tabular}




\begin{tabular}{|c|c|c|c|}
\hline $\begin{array}{c}\text { IV is changing } \\
\text { the traditional } \\
\text { culture of the } \\
\text { place }\end{array}$ & $\begin{array}{c}\text { Cultural } \\
\text { differences frame }\end{array}$ & $\begin{array}{c}\text { Material-benefit } \\
\text { frame }\end{array}$ & $\begin{array}{c}\text { IV can help create } \\
\text { material wealth in } \\
\text { the community }\end{array}$ \\
\hline $\begin{array}{c}\text { IV plays } \\
\text { favourites } \\
\text { during their } \\
\text { recruitment, } \\
\text { which creates } \\
\text { inequality in } \\
\text { the community }\end{array}$ & Inequality frame & $\begin{array}{c}\text { Egalitarianism } \\
\text { frame }\end{array}$ & $\begin{array}{c}\text { IV is concerned } \\
\text { about ensuring } \\
\text { social equity in the } \\
\text { community }\end{array}$ \\
\hline
\end{tabular}

Table 4: Framing contests and altered viewpoints

Evidently, then, the burden of applying corrective measures and altering the community's viewpoints invariably fall on ImS ventures, which are on the other side of the framing contests and have a lot to lose. To be sustainable in the long run, ImS ventures may have to both proactively and reactively engage in framing work to reshape the community's existing mental models. In IV's case, managers employed four different frame alignment mechanisms to influence the community and win the framing contests (see Column 3, Table 4). They tried to: (1) bridge the disconnected, but resonant framings of IV and the community (i.e., the progress frame) (2) extend the boundaries of their relationship with the community by invoking and projecting values that were already salient in the community (i.e., the family frame) (3) transform deeply entrenched meanings and values within the community (i.e., the material-benefit frame) and (4) amplify beliefs in the community (i.e., the egalitarianism frame). While the disgruntled voices in the community continue to counter-frame, on the whole IV's framing strategies has had a significant positive influence on how the community has come to perceive IV and its activities (see Column 4, Table 4). The competing framings of IV and the community is aligned to the extent that IV has successfully established five centres and employs close to 350 people, with more centres planned in the coming years. As an RL informant noted "What took us nearly three decades, IV seems to have achieved in five years,!" Figure 6 below pictorially depicts this process of alignment of the community's and IV's competing framings. It shows how ImS ventures use frame alignment mechanisms to win framing contests. Consequently, the community perceives the activities of the ImS venture in a more positive light leading to the accomplishment of frame alignment. 
However, it is important to recognize that from an ImS venture's perspective, outcomes of framing contests needn't always result in a happy alteration of existing viewpoints and the alignment of competing frames, as depicted in Figure 6 . The extent of success of an ImS venture's framing also depends on other cultural and political forces at play in the institutional environment. Drawing on our findings, we propose that framing contests between ImS ventures and the community may result in some combination of three outcomes - (1) the ImS venture successfully alters its image, overcoming opposition and resistance in the community (see Figure 6), (2) the ImS venture's image (held by the community) remains unaltered or takes a turn for the worse, in which case they may have to revise their frame alignment mechanisms and (3) the ImS venture's framings trigger serious internal disputes (e.g., about the overly social orientation of the senior management) and affect the viability of the business model.

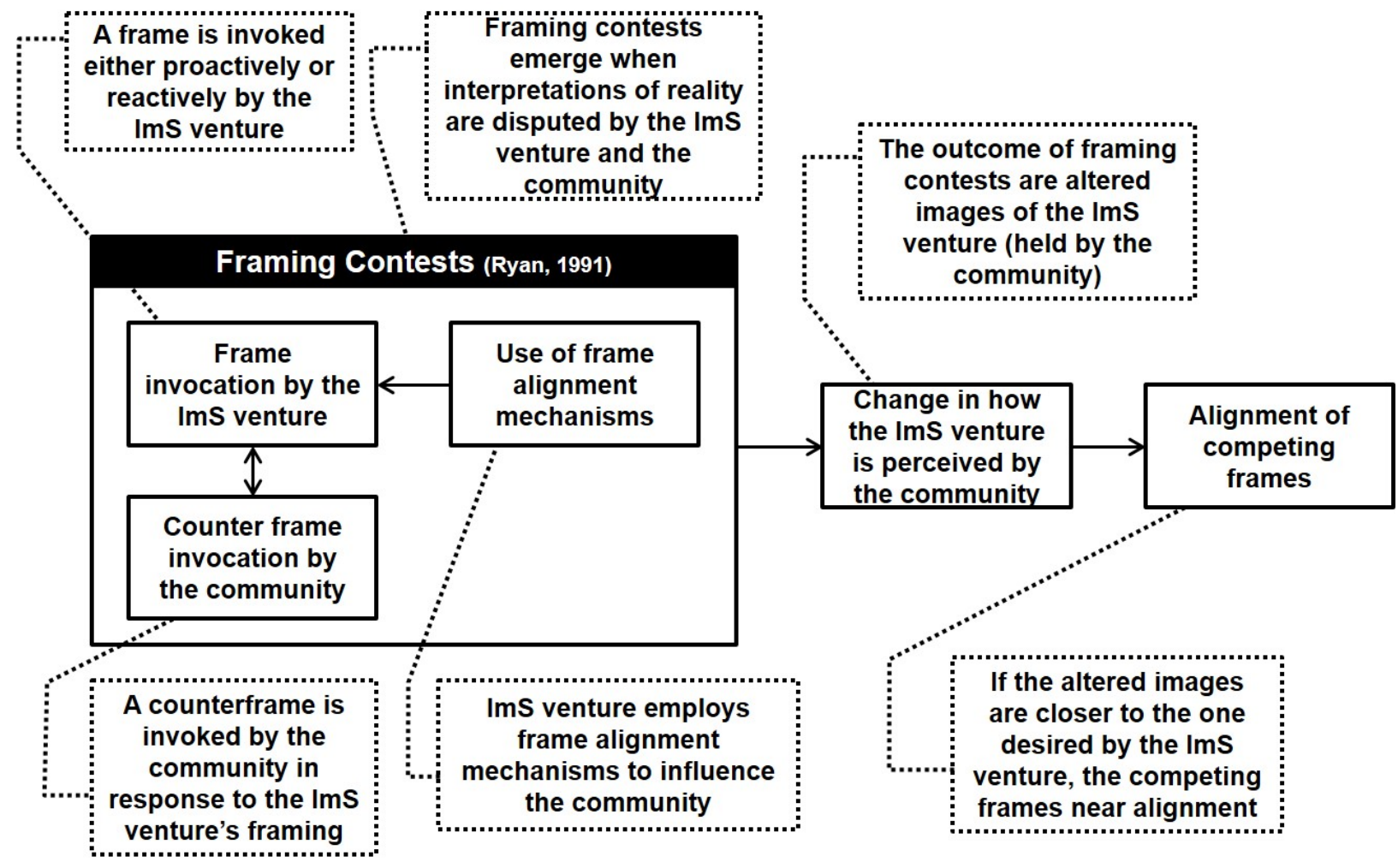

Figure 6: A process model of the alignment of competing frames

\section{Theoretical contributions}

This paper answers recent calls for research on the emerging ImS phenomenon (Carmel et al., 2013; Madon \& Sharanappa, 2013). It explores the day to day framing work undertaken by an ImS venture within a local community. The 
findings of our ethnographic study contribute to a better understanding of how competing framings of an ImS venture and the local community could reach alignment. The paper contributes to the literature on ImS in the following ways. First, it demonstrates that rural marginalized communities are more than just passive producers of IT-BPO services. The implicit portrayal of the communities as acquiescing to the establishment and growth of ImS ventures (see Accenture 2013; Monitor, 2011) appears to misrepresent the communities' fundamental cultural characteristics. To the contrary, this paper shows how and why communities utilize their agency to sometimes resist the ImS model. While there has been a general and cursory exploration of such opposition in relation to socio-economic hybrids (see Thomson \& Macmillan, 2010), our study has provided specific insights into why communities resist ImS ventures. We would argue that a community may resist ImS ventures for two main reasons: (1) perceived incompatibility of the ImS model with local norms and belief systems and (2) perceptions of inequality stemming from the merit-based recruitment strategies underpinning the model.

Second, our paper suggests that in order to be sustainable ImS ventures operating in marginalized communities may have to inject new values and beliefs into the community, which may openly contradict certain existing norms (see Seelos et al., 2010). While this may appear to be a patronizing act - deciding what is best in the community's interest - marginalized communities may not always be in the best position to fully appreciate the benefits of the ImS model, at least in the initial stages of a venture's operation. However, involving the community through consultations on a regular basis (such as the village advisory committee in this case) may inspire community participants to take ownership of key decisions. Third, our findings also demonstrate the strategic use of impression management (Elsbach et al. 1998) by ImS ventures. Indeed, impression management strategies are known to be used by firms to create and maintain positive images of their organization (Arndt \& Bigelow, 2000; Bansal \& Clelland, 2004; Ravishankar et al. 2013). While such strategies can help ImS ventures foster favourable impressions temporarily, our analysis suggests that a more lasting positive reputation for the firm can only be garnered through substantive actions taken over an extended period of time (see Gioia et al. 2000).

Finally, our paper emphasizes the critical influence of local communities on the sustainability of ImS ventures. Recent reports in the business and popular press 
have generated a great deal of excitement about the social and business potential of the ImS phenomenon. But they also appear to take local communities for granted. This does not mean, however, that academic research is similarly guilty of underplaying the importance of local communities. There is now a large body of research on ICT for Development (ICT4D) projects, which provide deep insights into the 'community' dimension in general and on the agency of marginalized communities in particular (see Heeks, 2006; Walsham \& Sahay, 2006; Zheng, 2009; Avgerou, 2010). Although many ICT4D projects seem to be government-led rather than private enterprise-driven, they are structurally similar to the ImS model in some ways. They have an overt social development agenda and the community's welfare is often at the heart of their operations. Many studies have reported extensively on the community's response to ICT4D projects. For instance, writing about an ICT4D project that focused on computer literacy in Siyabuswa (South Africa), Madon et al. (2009) have shown how getting symbolic support of the community in the early stages of a project may not necessarily ensure a project's scalability and sustainability as community members could later develop doubts about the real intentions of the project's promoters. Similarly, in an analysis of the Gyandoot telecenter project in Madhya Pradesh (India), Bailur (2007a) suggests that poor communities may not always possess the financial and cultural resources required to act as customers and thereby help telecenter entrepreneurs sustain their ventures. Clearly, the literature on ICT4D projects has a lot to offer to ImS research. Although the ImS business model is concerned with outsourcing of work, given its overt social orientation one may also view the model as a particular class of initiatives under the broader ICT4D umbrella. Clearly, ImS research will benefit from a closer engagement with ICT4D scholarship and further research on the ImS model needs to better integrate community-related insights from the ICT4D literature.

The paper contributes to the literature on frame alignment in the following ways. First, it suggests that framings related to progress, family, material-benefits frame and egalitarianism can help ImS ventures effectively manage their relationships with the local community. Second, the paper shows why framing strategies may be needed at all to establish and operate socially-oriented businesses in disadvantaged communities. Deliberate framings of a particular kind may not be required if all participants in an interaction share the same social reality. In any 
situation, if a particular projection of reality is the only one possible, and hence acceptable to everybody, there is little need for alternative framings of reality. That marginalized communities are almost always suspicious about the true intentions of ImS ventures implies that framings of ImS ventures are inevitably vulnerable and precarious. In a way it also serves as a reminder of how important, and (at the same time) difficult it is for social IT-BPO businesses to put on a believable performance in front of marginalized communities. Third, our study suggests that framing work can be either reactive - in response to an audience's framing work, or proactive - in anticipation of counter-framing by the audience. Finally, our study shows how in any given encounter, framing work is rarely one-sided. It is rarely the case that organizations can simply frame an aspect of reality in any way they choose to without encountering opposition from their audience. Although research often presents one side of the story (e.g., the social movements' perspective in Snow et al. (1986)), in reality underlying any broad framing work are sequences of micro framing contests.

\section{Conceptualizing the 'community' in ImS research}

The question of how ImS ventures frame their activities to marginalized communities raises an interesting point about the use of the somewhat allencompassing term 'community'. In our case, 'community' referred to the people living in and around five villages in a remote region of North India. IV informants consistently used the word 'community' when they spoke of people in this region. This perspective portrays a local community as a solid, homogenous entity that has a clear stake in the activities of ImS ventures. But in reality a community tends to comprise of people from different socio-economic and educational backgrounds and can be very diverse in terms of caste, age, class, ideology, attitudes and access to resources. Many community members could be disinterested in what an ImS venture has to offer or remain excluded from its field of operations. Indeed, research on ICT4D projects suggests that in some cases 'the community' could come to mean only a few people in a particular village. For instance, in a study of a community radio and IT project in South India, Bailur (2007b) reports on how the scope of the term 'community' had been reduced significantly at the time of the study and that it referred only to listeners of the radio station and self-help groups in the community. 
Unfortunately, many people in this community preferred watching entertainment shows on cable television over getting involved with the radio and IT project.

Building on this line of thought, we may need to exercise caution when claiming that a broadly-defined community is the intended beneficiary of ImS ventures' framing activities. In IV's case, one could instead make the more nuanced argument that the framing work was mostly directed at a proportion of people in the community whose support was absolutely essential for the company's operational continuity. Thus, breaking down the notion of a 'community' into its many complex constituent parts invariably diminishes the analytical scope and reach of the frame alignment concept as it is used here. While this insight does not invalidate the findings of our study, it suggests that as the level of analysis moves from macro to micro, we may need to speak of framing work directed at an 'audience', rather than at a 'community'.

\section{Practical implications}

Our paper contains several implications for ImS practitioners. First, setting up an ImS venture in a marginalized community is not a straightforward task. A range of social, cultural and political factors guide a community's world view. Therefore, practitioners may have to spend considerable effort in trying to understand the sociocultural and political contexts of the community. Being cognizant of these challenges may help managers of ImS ventures to craft suitable messages and strategies to negotiate resistance in the community. For example, managers can adopt a set of impression management techniques in anticipation of opposition from the community (see Elsbach et al., 1998). However, this focus on how ImS ventures frame their activities to gain support from the community does not necessarily imply that practitioners' framings are morally superior or that ImS managers always know what is in the best interests of the community. ImS ventures, regardless of how sophisticated and successful their prior business relationships, need to develop the humility to learn from local communities. Rather than define the problem in narrow and condescending terms as one of converting the community to their own worldview, ImS practitioners must also be open to the idea of working collaboratively with the community to achieve better outcomes. 
Second, many ImS ventures are enthusiastic, but may have limited experience of working with marginalized communities. Therefore, it may be helpful for ImS ventures to partner with a local organization or an influential individual, who enjoys high degrees of trust and respect within the community. Partnering with "locally embedded" (Jack \& Anderson, 2002) entities can possibly achieve two key objectives: (a) the respected local partner can help ImS ventures overcome their credibility and legitimacy deficits reasonably quickly, thus saving them valuable time, which they might otherwise have to expend to build trust within the community and (b) by "outsourcing" the work of liaising with the community to the partner, the ImS venture can focus on core business activities. This does not, of course, suggest that firms can be completely insulated from getting involved in the socio-cultural dynamics of the community. Aligning with a partner may be an important first step, but not always enough to ensure a community's acceptance of an ImS venture. Senior managers may have to proactively interact with the community from time to time to gain their trust and respect. ImS ventures could consider re-investing a proportion of their profits into projects that address the community's felt needs in areas such as education and health care.

Third, the hybrid nature of ImS ventures may impose certain singular challenges. Professionals hired by the organization may not always share the same levels of enthusiasm and vision for social change espoused by founding members. This could eventually lead to different framings of the organization's purpose and activities by internal constituents. To avoid such troubles, ImS ventures may choose to invest in "socialization" activities (Battilana \& Dorado, 2010) to ensure that the mental models of the internal constituents are aligned and congruent. For example, Battilana \& Dorado (2010, pp. 1426) describe how a microfinance institution enthused its workforce comprising of social workers and bankers by "converting the social workers to bankers and bankers to social workers". Similarly, ImS ventures can explore the possibility of introducing a socialization process wherein employees respectively holding strong business and social orientations can go through a process of "cross-learning". In other words, each cohort - business inclined and socially inclined - can learn from how the other group interprets reality and takes decisions. Such exercises may help reduce conflicts internally by making the process of organizational decision-making less ambiguous. Fourth, ImS ventures may also 
need to deploy 'culturally intelligent' hiring methods to ensure only the 'right' people preferably ambidextrous ones committed to both social and business concerns - are recruited. Finally, when deciding to start an ImS venture, entrepreneurs need to carefully take into account the broader institutional settings of the local community. In India for instance, some state governments are better governed and have investorfriendly policies and structures in place that provide better support to entrepreneurs, thus making it easier for them to run their operations. However, our informants observed that thus far only two out of India's 29 state governments have formulated policies explicitly in support of rural IT-BPO companies. In general, local communities in poorly-governed states seriously lack employment opportunities and therefore stand to benefit more from the presence of ImS ventures. At the same time, ImS ventures face the tough task of convincing clients that work of a reasonable quality can be delivered from such locations.

\section{CONCULDING REMARKS}

ImS is a burgeoning phenomenon drawing interest from various quarters academics, entrepreneurs, government agencies and international donor agencies. There is every possibility that the unbridled optimism surrounding this phenomenon could develop into a 'development bubble'. Therefore we call for a more thorough understanding of the challenges surrounding the sustainability of ImS ventures. To contribute to this endeavour, we set out by asking 'how do companies frame their ImS ventures to the local community?' - an important question whose answer has a direct and crucial bearing on the sustainability of the ImS model. The findings suggest that firms engage in a series of complex social-psychological frame alignment processes to influence their target audience - the local community. Further, our study also found that communities aren't passive receivers of the firm's framing activity, but in fact, respond strongly with counter-framings. The process model developed in the paper sheds light on how competing framings of the community and an ImS venture could eventually align.

We acknowledge two important limitations of our study. First, as noted earlier, we have used the over-arching term 'community'. This level of analysis carries the risk of not being fully sensitive to the subtleties of village life and to intra-community variations in behaviours. More research is required to understand the attitudes and 
lived experiences of specific marginalized groups (e.g., women) in relation to the ImS model. Although we spoke to a range of community informants, more microlevel analyses are required to understand the motivations and actions of different segments of a community. Second, although we have drawn largely on the frame literature, we must recognize that frame alignment alone does not necessarily guarantee the sustainability and success of the ImS model. A number of other institutional and contextual conditions also influence the trajectory of ImS ventures. For example, availability of governmental support, regional differences in attitudes to business and skill-levels of employees could play crucial roles in the success of ImS ventures. We have not explored these in any great detail and we would therefore suggest that frame alignment is perhaps best understood in concert with a range of other drivers. Given that research on $\mathrm{ImS}$ is still in its nascent stages, there is significant scope for future work (see Carmel et al. 2013). First, it would be interesting to study how ImS ventures' strategies vary across different social, cultural and geographical settings. Second, further research is required to compare and contrast the community-outcomes of socially-driven ImS models with the accomplishments of the more typical profit-oriented ventures.

\section{REFERENCES}

Accenture, 2012. Exploring the value proposition for Impact Sourcing: A buyer's perspective. [pdf] Available at: http://www.accenture.com/SiteCollectionDocuments /PDF/Accenture-Exploring-Value-Proposition-Impact-Sourcing.pdf [Accessed 14th November 2013].

Accenture, 2013. Recruitment, training and impact measurement: A recommended approach for impact sourcing. [pdf] Available at:

http://www.rockefellerfoundation.org/uploads/files/aafaca34-0502-4635-9491e608fff1d9df.pdf [Accessed 14th October 2014]

Arndt, M., \& Bigelow, B. (2000) Presenting structural innovation in an institutional environment: Hospitals' use of impression management. Administrative Science Quarterly, 45, 494-522.

Avgerou, C. (2010) Discourses on ICT and development. Information Technologies \& International Development, 6, 1-18.

Bailur, S. (2007a) Using stakeholder theory to analyze telecenter projects. Information Technologies \& International Development, 3, 61-80.

Bailur, S. (2007b) The complexities of community participation in ICT for development projects: The case of 'Our Voices'. Proceedings of the 9th International 
Conference on Social Implications of Computers in Developing Countries, São Paulo, Brazil.

Bandyopadhyay, T. \& Unnikrishnan D. (2013) SKS microfinance: The inside story. Available at: http://www.livemint.com/Industry/hvWN2lb\|lrX5hXKj3keERL/SKSMicrofinance-The-inside-story.html

Bansal, P. \& Clelland, I. (2004) Talking trash: Legitimacy, impression management and unsystematic risk in the context of the natural environment. The Academy of Management Journal, 47, 93-103.

Bateson, G. (1972). Steps to an Ecology of Mind. Ballantine: New York.

Battilana, J. \& Dorado, S. (2010) Building sustainable hybrid organizations: The case of commercial microfinance institutions. Academy of Management Journal, 6, 14191440.

Battilana, J., Pache, A.C., Sengul, M. \& Model, J. (2013) Combining social welfare and market logics: What drives social performance in socio-economic hybrids? In The Academy of Management. The $72^{\text {nd }}$ Annual Meeting of the Academy of Management, Boston, USA, 2012.

Benford, R.D. (1993) Frame disputes within the nuclear disarmament movement, Social Forces 71, 677-701.

Benford, R. D. and D. A. Snow (2000) Framing processes and social movements: An overview and assessment, Annual Review of Sociology, 26, 611-639.

Bhyrappa, S.L. (2003) The Crossing Over (Gurudatta, P. \& Mowat, D., Trans). B.R. Publishing: Delhi

Breman, J. (2007) The Poverty Regime in Village India: Half a Century of Work and Life at the Bottom of the Rural Economy in South Gujarat. Oxford University Press:Delhi.

Carmel, E., Lacity, M. and Doty, A. (2013) The Impact of Impact Sourcing: Framing a Research Agenda. $4^{\text {th }}$ International Conference on the Outsourcing of Information Services, Mannheim, Germany.

Cohen, L. \& El-Sawad, A. (2007) Lived experiences of offshoring: An examination of UK and Indian financial service employees' accounts of themselves and one another. Human Relations, 60,1235-1262.

Cornelissen, J.P. \& Werner, M.D. (2014) Putting framing in perspective: A review of framing and frame analysis across the management and organizational literature. The Academy of Management Annals, 8, 181-235.

Cress, M.D. \& Snow, D.A. (2003) The Outcomes of Homeless Mobilization: The Influence of Organization, Disruption, Political Mediation, and Framing. American Journal of Sociology, 105, 1063-1104.

Elsbach, K. D., Sutton, R. I., and Principe, K. E. (1998) Averting expected challenges through anticipatory impression management: A study of hospital billing. Organization Science, 9, 68-86. 
Evans, J.H. (1997) Multi-organizational fields and social movement organization frame content: the religious pro-choice movement. Sociological Inquiry, 67, 451-469.

Friedman, T.L., 2004. Thomas L. Friedman reporting: The other side of outsourcing. [video online] Available at: http://vimeo.com/14287759 [accessed $14^{\text {th }}$ October 2014].

Gino, F. \& Staats, B.R. (2012) The Microwork solution. Harvard Business Review, 90, 92-96.

Gioia, D.A, Schultz, M. \& Corley, K.G. (2000) Organizational Identity, Image and Adaptive Instability. Academy of Management Review, 25, 63-81.

Goffman, E. (1974) Frame analysis: An essay on the organization of experience, Harper and Row, New York.

Heeks, R. (2006) Theorizing ICT4D research. Information Technologies \& International Development, 3, 1-4.

Heeks, R. \& Arun, S. (2010) Social outsourcing as a development tool: The impact of outsourcing IT services to women's social enterprises in Kerala. Journal of International Development, 22, 441-454.

Heeks, R. (2013) Information Technology Impact Sourcing. Communications of the ACM, 56, 22-25.

Jack, S.L. \& Anderson, A.R. (2002) The effects of embeddedness on the entrepreneurial process. Journal of Business Venturing, 17, 467-487.

Jodhka, S.S. (2014) Caste in Contemporary India, Routledge, Delhi.

Koppman, S., Matarelli, E. \& Gupta, A. (2013) The interpretive work of offshore professionals in intercultural collaborations. In The Academy of Management, The $73^{\text {rd }}$ Annual Meeting of the Academy of Management. Orlando, USA, 2013.

KPMG (2012) Hub and spoke operating model: A new business paradigm for the Indian IT-BPO industry. Available at:

http://www.kpmg.com/IN/en/IssuesAndInsights/ThoughtLeadership/Hub-and-spoke-

$\underline{\text { model.pdf }}$

Klein, H. K. \& Myers, M.D. (1999) A Set of Principles for Conducting and Evaluating Interpretive Field Studies in Information Systems. MIS Quarterly, Special Issue on Intensive Research, 23, 67-93.

Lacity, M.C., Rottman, J. \& Carmel, E. (2014) Impact Sourcing: Employing Prison Inmates to Perform Digitally-enabled Business Services. Communications of the Association for Information Systems, 34, 913-932.

Lacity, M.C., Rottman, J. \& Khan, S. (2010) Field of dreams: building IT capabilities in rural America. Strategic Outsourcing: An international journal, 3,169-191.

Leonardi, P.M. (2011) Innovation blindness: Culture, frames, and cross-boundary problem construction in the development of new technology concepts. Organization Science, 22, 347-369. 
Madon, S., Reinhard, N., Roode, D. \& Walsham, G. (2009) Digital inclusion projects in developing countries: Processes of institutionalization. Information Technology for Development, 15, 95-107.

Madon, S. \& Sharanappa, S. (2013) Social IT sourcing and development: Theorizing the linkage. Information Systems Journal, 23, 381-399.

Marquis, C. \& Battilana, J. (2009) Acting globally but thinking locally? The enduring influence of local communities on organizations. Research in Organizational Behaviour, 29, 283-202.

Monitor, 2011. Job creation through the field of Impact sourcing. [pdf] Available at: http://www.rockefellerfoundation.org/blog/job-creation-through-building-field [Accessed 16th October 2013].

Myers, M.D. (1999) Investigating information systems with ethnographic research. Communications of the AIS, 2, 1-20.

Prahalad, C.K. \& Hart, S.L. (2002) The fortune at the bottom of the pyramid. Strategy+Business, 26, 1-14.

Porter, M. and Kramer, M. (2011) Creating shared value, Harvard Business Review, 63-77.

Ravishankar, M.N. (2014) The realignment of offshoring frame disputes (OFD): an ethnographic 'cultural' analysis. European Journal of Information Systems, in press, doi:10.1057/ejis.2014.5.

Ravishankar, M.N. (2013) Public ICT Innovations: A strategic ambiguity perspective. Journal of Information Technology, 28, 316-332.

Ravishankar, M.N., Cohen, L. \& El-Sawad, A. (2010) Examining resistance, accommodation and the pursuit of aspiration in the Indian IT-BPO space: reflections on two case studies. Industrial Relations Journal, 41, 154-167.

Ravishankar, M.N., Pan, S.L. \& Myers, M.D. (2013) Information technology offshoring in India: A postcolonial perspective. European Journal of Information Systems, 22, 387-402.

Rockefeller, 2013. Digital Jobs: Defined. [online] Available at: http://www.rockefellerfoundation.org/our-work/current-work/digital-jobs-africa/digitaljobs-defined [Accessed 1st November 2013].

Ryan, C. (1991) Prime time Activism: Media Strategies for Grassroots Organizing. Boston: South End.

Sandeep, M.S. \& Ravishankar, M.N. (2013) The other India. Professional Outsourcing, 13, 14-20.

Sandeep, M.S., Ravishankar, M.N. \& Hislop, D. (2013) The Establishment of social IT sourcing organizations: An impression management perspective. In Association of Information Systems, Proceedings of the International Conference on Information Systems, Milan, Italy, 2013. 
Seelos, C., Mair, J., Battilana, J. and Dacin, M.T. (2010) The embeddedness of social entrepreneurship: Understanding variation across local communities, in C. Marquis, M. Lounsbury and R. Greenwood, Research in Organizational Sociology on Communities and Organizations. UK: Emerald.

Snow, D.A. \& Byrd, S.C. (2007) Ideology, Framing Processes and Islamic terrorists movements. Mobilization: An international quarterly, 12, 119-136.

Snow, D.A., Rochford JR., E.B., Worden, S.K. \& Benford, R.D. (1986) Frame alignment processes, micromobilization, and movement participation, American Sociological Review, 51, 464-481.

Srinivas, M.N. (1976) The Remembered Village. Oxford University Press, Delhi.

Strauss, A. \& Corbin, J. (1998) Basics of Qualitative Research: Techniques and Procedures for Developing Grounded Theory, 2nd edn. Sage, Thousand Oaks, CA.

Thompson, J.D. \& Macmillan, I.C. (2010) Business Models: Creating new markets and Societal wealth. Long Range Planning, 43, 291-307.

Tracey, P., Phillips, N., \& Jarvis, O. (2011) Bridging institutional entrepreneurship and the creation of new organizational forms: A multilevel model, Organization Science, 22, 60-80.

Van Maanen, J. (1979) The Fact of Fiction in Organizational Ethnography. Administrative Science Quarterly, 24, 539-550.

Walsham, G. (1993) Decentralization of IS in developing countries - Power to the people. Journal of Information Technology 8, 74-81.

Walsham, G. (1995) The emergence of interpretivism in IS research. Information Systems Research, 4, 376-394.

Walsham, G. \& Sahay, S. (2006) Research on information systems in developing countries: Current landscape and future prospects. Information Technology for Development, 12, 7-24.

Zheng, Y. (2009) Different spaces for e-development: What can we learn from the capability approach? Information Technology for Development, 15, 66-82. 